\title{
4 Chinese English, English Chinese: Biliteracy and Translation
}

\section{Elaine Yee Lin Ho}

In the past decade, local activism has encouraged public interest in cultural identity but there is little doubt that the global attention on Hong Kong evident around 1997 has receded. As one local historian and sinophone literary scholar lamented, Before 1997, Hong Kong was the focal point of the world. Everywhere, there was 'Hong Kong fever', and a whole mass of publications on many areas of Hong Kong appeared .... Unfortunately, this turned out to be a 'five-minute fever'. After $1997 \ldots$ all that was splendor returned to quietude. Very quickly, everything seemed to have fallen back into silence.

九七前夕，香港曾經是全世界焦點，四處都鬧哄哄的出現「香港熱」，各種 各樣有關香港的著作出了一大堆...可惜的是，這原來只不過是五分鐘的熱

度，九七過後...絢爛很快便歸於平淡，一切都好像在瞬息間沉靜下來。

(Wong, 2007, pp. 176-7).

The years before and after 1997 did witness an unprecedented surge of activity in research and publications on Hong Kong, notable among which was the work of Wong Wang-chi (王宏志) and his collaborators (see, for example, Wong et al. 1997, Wong 2000) Such work disseminated into the discourse on Hong Kong cultural identity and politics perspectives on the "local" opened up by Western post-structuralist and postcolonialist thinking. They critiqued various attempts to translate a globally disseminated theoretical discourse on hybridity (and related terms) into specificities of 
Hong Kong cultural identity. At the same time, they made sustained efforts to conceptualize a non-essentialized "local" in terms of the postcolonial paradigm of "hybridity". Gesturing towards Hong Kong's colonial past, this discourse often posits hybridity in terms of interwoven Chinese (Zong) and English (Ying) elements (see Lee in Wong et al 1997; Chan in Wong et al 1997; Wong 2000). But surprisingly, Zong and Ying rarely refer to actual languages. The silence on this point is surprising for at least three reasons: first, the linguistic turn instantiated in much post-structuralist and postcolonial theorizing; second, the language issue as a nexus of ongoing postcolonial contestation globally; third, and crucially, how Chinese and English, as linguistic media in interaction, inscribe and transcribe the movements of the local as hybrid.

The third reason develops a particular urgency in view of the official HKSAR policy of biliteracy (Chinese and English) and trilingualism (Cantonese, Putonghua, English) announced in the Chief Executive's policy address in 1999. The policy address sought to define within a wider aspirational framework measures concerning medium of instruction announced two years earlier, and to legitimize these measures. In 1997, the "Medium of Instruction Guidance" issued by the Education Department stated that a school should use Chinese as the medium of instruction unless it could demonstrate that its teachers and students were proficient to teach and learn in English. After a year, only 114 of the 411 secondary schools in Hong Kong were designated English medium; others with English medium status had to change to Chinese (Cantonese or Putonghua), and those that had planned to change to English found their plans thwarted. There was immediate outcry and protests from schools, pupils and parents, and their pressure on the government had never slackened in the decade since 1997. Recently, in 2009, the 
government decided to adopt what it called “fine-tuning” (微調), allowing schools to choose which medium of instruction to use and in which subject. This effectively means the abandonment of the 1997 policy and a return to the pre-1997 situation. ${ }^{1}$

Language policy issues were by no means straightforward before 1997, and the passion they can arouse in the public domain has been repeatedly attested to in the years since the handover. The medium of instruction controversy - important though it undoubtedly is — has telescoped Hong Kong's complex linguistic geography so that it has become largely visible as a single issue. It has created a situation where public debate over language use becomes excessively focused on oral performance and classroom and pedagogical competency at the expense of other aspects and contexts of language use that "biliteracy" and "trilingualism" ${ }^{2}$ involve. Because biliteracy concerns reading and writing rather than speech, it is even more overshadowed, so much so that conceptual discussion of what constitutes biliteracy that can draw upon actual language use in a social domain beyond the classroom rarely merits attention. Until now, the notion of Chinese English hybridity in Hong Kong language use has largely been studied by linguists under the framework of "code mixing" and "code switching." 3 Focusing on the spoken language, scholars describe and categorize intralingual features, and inquire into who is or is not bilingual with references to language acquisition and development. Sociolinguists situate intralingual features in relation to different media, social class, and larger demographic movements (see Li, 1996; Pennington, 1998). ${ }^{4}$ But rarely visible in Hong Kong is research in which cultural identity is posited as a conceptual category or process that language use inscribes and transcribes.

Comment [u1] : See note
4 please. The ending reference
to "Li and Lee 28.3.1" is a
format that is unclear. Do you
mean chapter 28 of the 2005
book? Citing the page
numbers in the book, and
paragraphs if necessary,
would be clearer. Please
consider making this change.


Thus until now, studies of cultural identity in Hong Kong have been inflected, on the one hand, by the paradigm of hybridity that seldom deals with issues of languages. On the other hand, studies of bilingual language use in Hong Kong tend to be focused almost exclusively on code mixing or code switching but rarely as a phenomenon of cultural hybridity. In light of this situation, this chapter wishes to study biliteracy or bilingualism not through code mixing but the multifocal lens of translation. Translation studies scholars engage with language as artefact and effect, and theorizing about crosslinguistic and cross-cultural encounters. This will help forge connections between biliteracy and cultural identity, and trace how cultural hybridity emerges from the exchange between Chinese and English. The dynamic changes in translation studies in recent decades make its choice even more compelling. Besides having outcomes for translation practice these changes also generate conceptual rethinking that affiliates with critical and cultural theories. Furthermore, , translation, as Haun Saussy observes, is "one of the metaphors of our time", traversing comparative and world literary studies, discourses on globalization and cosmopolitanism, and media and communication (Saussy, 2008, p.1).

This essay will first give an account of recent translation studies and delineate the critical issues about language and cultural identity that it raises. These issues will then frame detailed discussions of three sets of Hong Kong literary texts in both Chinese and English as instantiations of biliteracy; each of these sets can posit a way of seeing, or a modality, of biliteracy. Translation studies can help disclose the insights of these 
modalities for both language use and cultural identity. Against the separatist view that assigns "mother tongue" and "native speaker" proficiency to languages, this essay explores the three sets of texts as examples of interlingual practice that have different outcomes for cultural identity. Each set of texts locates a particular horizon of possibility toward — or against — which both discussion and uses of English and Chinese vis-àvis each other may proceed. The elaborations of these texts as translational language use and cultural identity will also reveal their internal contradictions, and may generate further discussion, adaptation, and inventiveness.

\section{Translation}

Like other literary and language-based studies, translation as an academic subject has been destabilized by post-structuralism's radical critique of origins. The traditional source-target formulation of translation is founded on the concept of an original or source text in one language, and the assumption that its meaning is transparent and can be reproduced with some exactitude in another language or target system. This places the demands of fidelity and equivalence upon the translator whose responsibility is conceived of as the preservation of the meaning of the original, and whose labour is largely assessed in technical terms. But the absolute power of the original over the translation and translator, in the light of Walter Benjamin's critique ("The Task of the Translator") and that of poststructuralist thought, has been seriously challenged. Far from faithfully reproducing the original, Maria Tymoczko submits, "Translators select some elements ... of the source text to highlight and preserve ..., prioritize and privilege some parameters and not others ..., represent some aspects of the source text partially or fully or others not 
at all in a translation. By definition, therefore, translation is metonymic: it is a form of representation in which parts or aspects of the source text come to stand for the whole" (Tymoczko, 1999, p. 55). This is tantamount to an acknowledgement that traditional standards of fidelity and equivalence are neither practised nor possible in practice.

Earlier, Lawrence Venuti (1992) has challenged originality and equivalence as myths that conceal how translation conforms to existing cultural and social hierarchies. To Venuti, thinking from the traffic of foreign literature into America, traditional translation performs the task of domesticating the foreign, enabling readers to recognize the familiar in the unfamiliar. In shedding a foreign culture of its difference, translation enacts a form of cultural assimilation that is neo-imperialistic. Against this practice, Venuti advocates a reconceptualization of translated texts as comprised of multiple discourses and linguistic features that intermix references to the cultural semiotics of both source and reception. In this description of selectivity that Tymoczko would later call metonymic, the translator can devise tactics that resist the impositions of dominant cultural or ideological views. More recently, the Hong Kong translation studies scholar, Matthew Leung (2006) has given an account of the "ideological turn" that follows on from the "linguistic" and "cultural" turns in his subject area.

Germane to my argument is how such recent theorizing articulates the critique of translation to the critique of cultural identity as a function of power. This articulation is captured in postcolonial translation studies and its research into translation's complicity with colonial constructions of knowledge and the other (Bassnett and Lefevre, 1990; 
Bassnett and Trivedi, 1999; Tymoczko, 1999). ${ }^{5}$ Susan Bassnett has made the crucial conceptual link between translation and colonialism's commitment to the stability and superiority of the original, and historicized it in the context of European imperialism in the nineteenth and twentieth centuries: “...Europe was regarded as the great Original, the starting point, and the colonies were therefore copies, or 'translations' of Europe, which they were supposed to duplicate. Moreover being copies, translations were evaluated as less than originals, and the myth of the translation as something that diminished the great original established itself" (Bassnett, 1999, p. 4). Critics have also shown how the target or translated text in the colonizer's language can disorient the indigenous source's semantic compass, and dispossess it of its cultural power (Basnett and Trivedi, 1999; Cheyfitz, 1997; Niranjana, 1992; 2002) In a significant shift of focus to the agency of the colonized, Gentzler and Tymoczko have argued that "translation is not simply associated with ... colonization or oppression, but also with 'the ability to act upon' structures of command, such that translation becomes a means to resist that very colonization or exploitation" (2002, p. xvii).

One of the most dynamic interflows between translation and postcolonial studies occurs under the sign of hybridity. Michael Cronin's description of the translator as "floating in an entre-deux (home/away, source language / target language, mother tongue / non-mother tongue)" (2000, p. 138) strongly resonates of the unstable, ambivalent subjectivities in between cultures and discourses that postcolonial studies theorize and historicize. In Cronin's latest study (2006), the translator's language-based, practical work is seen as the everyday performance of an intercultural subjectivity. Translation as 
metonymic and a translational subjectivity as a trope of identity - Cronin articulates these two registers of translation discourse as paradigmatic of the contemporary flows connecting local and global. Bermann and Wood have called translation "an important border concept in the humanities" (2005, p. 5), an allusion to its ability, actual and potential, to traverse and contest disciplinary boundaries (see also Duarte et al.).

The critique of origin and equivalence; translation's complicity with and resistance to dominant power; translation as hybridizing process, and as the contemporary trope of cross-boundary identities and discourses: the multidimensionality of translation studies helps to articulate a conceptual framework for the study of three sets of EnglishChinese texts — Leung Ping-kwan's “An Old Colonial Building” / 「老殖民地建築 」, Wong Man’s “Indulgence” /「縱任自己」, and Tammy Ho Lai-ming’s “Going to My Parents' Place on a Crowded Bus" and 「我家」(English title translated by author as "My Home"; see Ho, 2008). However, only the first set of poems can be considered translations in the conventional sense. The other two are translational in that the multiple perspectives that translation studies have opened up throw light on their thematics, significations, and as tropes of cultural identity that play on the simultaneity and distance of two languages. My readings do not focus on individual writers as biliterates, or their texts as exemplary models that can be reduplicated, or as misprisions to be inveighed against. The point of emphasis is on the sets of texts as modalities of biliteracy that are situated locally and globally. What emerges from the traffic between English and Chinese, the space that conjoins and separates the two languages is the subject of this essay's critical inquiry. In attending to the "I", the first-person subject positions that mark, and is 
marked by this traffic, the essay studies a discourse of identity generated by the texts in relations that are forged by a literacy that is bilingual and interlingual. The relational dynamic can be discerned at a number of levels simultaneously — in content and thematics, as formal equivalence and distantiation of two semiotic systems, and in how biliteracy enables the texts to turn in various directions on the double axes of the local and global. In its referentiality, this "I" that is elaborated in each set of double language texts develops contemporary significance at a time when language as oral and educational medium dominates public attention, and relations between biliterate language use and cultural identity are rarely studied in Hong Kong.

\section{“An Old Colonial Building” / 「老殖民地建築」}

\section{Leung Ping-kwan’s (Ye si 也斯) “An Old Colonial Building” / 「老殖民地建築」was}

first written in Chinese in October 1986, and translated into English by Michelle Yeh for the 2002 anthology, Travelling with a Bitter Melon / 《帶一枚苦瓜旅行》(pp. 318-9, see Figure 4.1). ${ }^{6}$ In the poem's thematics, Hong Kong's history as colonial, fixed in the material form of a building, is dislodged by a postcolonial sensibility, and rewritten as an ongoing itinerary of everyday social life and activities. The titular structure is the Main Building of the University of Hong Kong, long regarded as the icon of the university's status as the oldest higher educational institution in Hong Kong and by the more stringent members of the general public as the unmistakable sign of a colonial institution. Its exterior, a composition of red-brick and neo-classical columns, is of an architectural style replicated in major public buildings that define the urban landscape of the British empire. Construction began in 1910, the year the university's foundation stone was laid; the 
building survived bomb damage in World War II, and is now one of the few large-scale colonial landmarks remaining and named as "Declared Monuments". 7 This monumentalism, a function of its colonial-institutional history, often renders invisible the ordinary activities and informal sociality that are the everyday life of the Main Building. It is this everyday life that the poem narrates, as an itinerary of ongoing movement and a passage through shifting visual signs.

\section{Figure $\underline{4} 1$}

In the poem, the building as monument is first demolished and then remade. The doubled sense of the building as original - the first of its kind in Hong Kong and being recognized as such and declared monumental — is countered by the poem's double act of destructuration and recomposition. The building translated, a function of this double act, becomes recognizable only through the fragments of the origin reassembled. But like Walter Benjamin's famous "broken vessel", this reconfiguration actually serves to undermine further the concept of an origin in its own time and its epistemological authority over all succeeding temporalities. What coordinates the building, the postcolonial, and the everyday is movement, or time and motion, sometimes embodied in a mobile subject — for example, in stanza two when the "I" appears. History is localized in the itinerary of the subject "I" moving in time; time's passage is recalibrated in the subject's movements as he takes apart the building's original structure and selectively reconfigures it as habitat. 
Alternatively, as for example in stanza one, the speaking subject is implicit. It seems time and motion itself, rather like that enacted by a moving camera, is passing down corridors, zooming in and out, so that the dust, the shadow, the scaffolds, the repair and renovation work that is going on, the stairs that connect the building with others move in and out of view. The building re-presents itself as serial spaces of everyday signification whose metonymy is the pond "of shimmering water with floating signs" (p. 319). The significant function of this cinematic narrative is to identify the time of the building's dislocation and recomposition with present time - the building's interior is turned inside out in a temporality of present movement. At the same time, the double act is re-performed every time the poem is read, and with every reading, its moment of origin, October 1986, is displaced. Without a beginning or origin, an ending makes no sense: in both its thematics and reading effect, the poem affirms that everyday as translational poeisis is always in the present. This point is made even more explicit in the English translation which is throughout in the present tense.

The poem is about beginnings and endings from another point of view. It captures the juncture of colonial end-time, but clearly eschews a nationalist point of view that celebrates a new era "in banners or fireworks in the sky". Nor does it see the juncture as the inaugural moment of a community of the "local", a bond of "you" and "I" as the substance of a realist poetics: “... In the midst of changes / our thoughts neither evade the ripples nor bend in the breeze. / I know you don't believe in banners or fireworks in the sky. / These broken words of mine don't claim to be realistic / nor are they the centre surrounded by highrises, just a pond / of shimmering water with floating signs". 
……在變化中

思考不避波動也不隨風輕折

我知你不信旗幟或滿天煙花

我給你文字破碎不自稱寫實

不是高樓圍繞的中心只是一池

粼粼的水聚散著遊動的符號 (p. 318)

Neither colonialism nor nationalism can assert its claim as the source of history reconstituted as everyday Hong Kong life and subjectivity. The poem's multidirectional critique of stadial historical time criss-crosses anti-colonial, nationalistic, and communitarian discourses. In so doing, its subjectivity skirts nimbly around ethnicized binaries of self and other. The way Leung writes about a colonial building is not identifiably anti-British or anglophilic-nostalgic or conservationist of British colonial heritage. Nor does it imply support for Chinese narratives with their imperative of return to an ethnocultural "homeland".

The two poems as language performances in Chinese and English confirm its nonethnicized thematics. Written in Chinese, the poem does not suggest in any way that its language choice is either anglophobic or sinophilic. Language choice has been represented as a political act in the transitional poetics from colonialism to nationalism, as the example of the Kenyan novelist Ngugi wa Thiong'o famously argues. ${ }^{8}$ In Hong Kong, national reversion can be seen as one of the motivations behind the government's 1997 directive to the majority of schools to change to Chinese medium. A decade before 1997, Leung Ping-kwan's sinophone poetics already eschews an organic bond between indigenous language and nationalist culture. In this respect, it inscribes a specific, "local" translation - as departure and difference rather than similitude - from a global 
postcolonial discourse in which colonial end-time is coeval with the resumption of indigenous culture and language. At the same time, it also transcribes a resistant strain to this discourse in Hong Kong's language and cultural politics in the run-up to1997.

What then of the poem's translation into English? Between its first publication date and appearance in translation, the poem straddles pre- and post-1997. In that time, as if going in reverse, it has moved from Chinese to English. Given the poem's translational poeisis that I discuss above, what does its actual rendering into English signify? What issues of temporality does this accession of English argue? How does the availability of the poem in English elaborate or problematize its micro-politics of the local? My queries are not about the translation per se. It abides by the rules of fidelity and equivalence; only if one were to fetishize small differences would one see the punctuation added as a possible disruption of the seamless itinerary of mobility the source text foregrounds.

From one point of view, the English translation articulates the poem's critique of origins and the monumental to a global postcolonial discourse, and in so doing, situates the poem in a different horizon from the local. One may well argue that the postcolonial critique is already embedded in the Chinese source text. So the English translation, in rendering the poem's postcoloniality as global, is also a form of back translation that draws attention to the poem's localized beginnings.. The translation also enables the poem's entry into a contemporary discourse of world literature conceptualized as boundary-crossing, that contests monumentalized national literatures on the one hand, and on the other, reductive generalizations about nation and culture in positivistic area 
studies. ${ }^{9}$ While the Chinese source text represents an alternative horizon of seeing, the translation reconstitutes the poem in yet other horizons. Thus, the poem's de-ethnicizing agenda may be renewed as it is studied as an act of trans-global literary performance. Or, if incorporated into a schema of world literature like Franco Moretti's, it may be reethnicized as specifically "Hong Kong" in its references to British-colonial and Chinesenational discourses. ${ }^{10}$

There is the risk that world literature runs of becoming the discourse of "angloglobalism", as Jonathan Arac has warned, and thus, for Leung's translation to become complicit in it. In other words, the poem could be seen to have broken free of the shackles of an earlier colonization only to become resubjected in late modernity to the function of English as "privileged link in the teleological chain of globalisation" (Cronin, 2000b, p. 113). Arac posits the contemporary agenda of English and world literature through referencing Edward Said's early work on Joseph Conrad, an agenda that "transforms the study of English ... as it addresses the current conditions of world literature in a state of globality - the formal and psychological question of the interdependence of literary and sociological approaches in dealing with how English ... is at once a national and a world language (for some writers a first and for others a second language)" (Arac, 2002, p. 44). Adapting Arac, one can ask: reading Leung's poem and its translation, how does it conceive of the issue of English as a Hong Kong - that is, local if not "national" - language? A second language for Leung and for the many like him who can read the sinophone source text? An everyday language? 
What the translation's grammar usefully makes explicit, as we have seen, is the ever-present nature of the poem's itinerary. But it is precisely on this formal point that the poem's voicing of what Andreas Huyssen has called "an earlier activist imagination of the future" is at its most equivocal (Huyssen, p. 5). The translation of Leung's poem from Chinese to English paradoxically brings back the concept of origins, one that the poem so explicitly deconstructs. Indeed, one may say that both the concept of origin and the poem as original are reborn through translation. In this second coming, Chinese is once again prior, the authentic source, and English, the copy - a superb copy it may be but one that a reader of Chinese may well dismiss or simply ignore.

Historicizing this formal logic, as a Hong Kong text, the identity of the "local" enacted in the poem and its translation speaks not of hybridity but of Chinese as core, primary, and the medium of an authentic expressivity and communicative discourse. English, in contrast, is secondary and, insofar as it enables the sinophone subject to enter contemporary globality, utilitarian. Here, translation as an intercultural act also paradoxically enables continued discrimination between Chinese and English in a hierarchy of value - literary, conceptual and sociocultural. Arranged along a unilinear trajectory from local to the world, the target text in English continues the decolonizing and de-ethnicizing itinerary of the Chinese source. Read against each other, however, the appearance of the English rendering of the Chinese text raises the issue not only of complicity with anglo-globalism but also a return to an ethnolinguistic identity as authentic. 
The point here, I wish to emphasize, is not whether Leung's poems should or should not be translated into English - or indeed into any other language. What is at stake is that a pre-1997 poem situated in a denationalizing and de-ethnicizing critique of identity can, through its translation post-1997, be reinscribed into precisely what it critiques. The implications are profound for it argues that biliteracy, instantiated as literal translation from one language to another, is a double and ambivalent act: an act of departure from and of reversion to an origin. If English is indeed the lingua franca of current globalization, it is also the language by which the "worlding" of Hong Kong takes

place. ${ }^{11}$ But this "worlding" through English is also emphatically an affirmation of Hong Kong's original Chineseness. Thus access to and being accessible through both English and Chinese do not, and cannot, be automatic indicators of Hong Kong's cultural hybridity and cosmopolitanism.

\section{“Indulgence” /「縱任自己」in Between Two Worlds / 《在兩個世界之} 間》

Leung's Chinese poem and its English translation appear as parallel texts in the 2002 collection, an appearance that create a simulacrum of parity and simultaneity between them and, by indirection, the two languages. Publication in parallel texts is most often associated with translation practice. However, as a form of self-and-other-representation, it can have multiple ramifications for identity discourse. What I wish to speculate on next is how in parallel texts a translational subjectivity is made visible without invoking the hierarchies of origin-copy that literal translation puts in place. At this point my chapter 
ruptures from - or in De Certeau's words, enters into "a relation of indebtedness and rejection" (De Certeau, 1988, p. 2) with — translation studies.

To further probe parallel texts as biliterate modality, I would like to discuss the poem "Indulgence" /「縱任自己」; it was published in 1956 in a volume of poems in parallel English-Chinese texts called Between Two Worlds / 《在兩個世界之間》by Wong Man (黄雯). ${ }^{12}$ (see Figure 4.2) 
報章晨利標题“中國水災”，

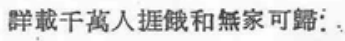
常然是無情政府

和会官污吏所造成:

思, 把學校功課留待明天吧

賞夏日陽光正眼照 倫敦卵阅板球劫的線油油草地,

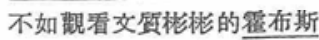
替落立郡打個一百記錄能。

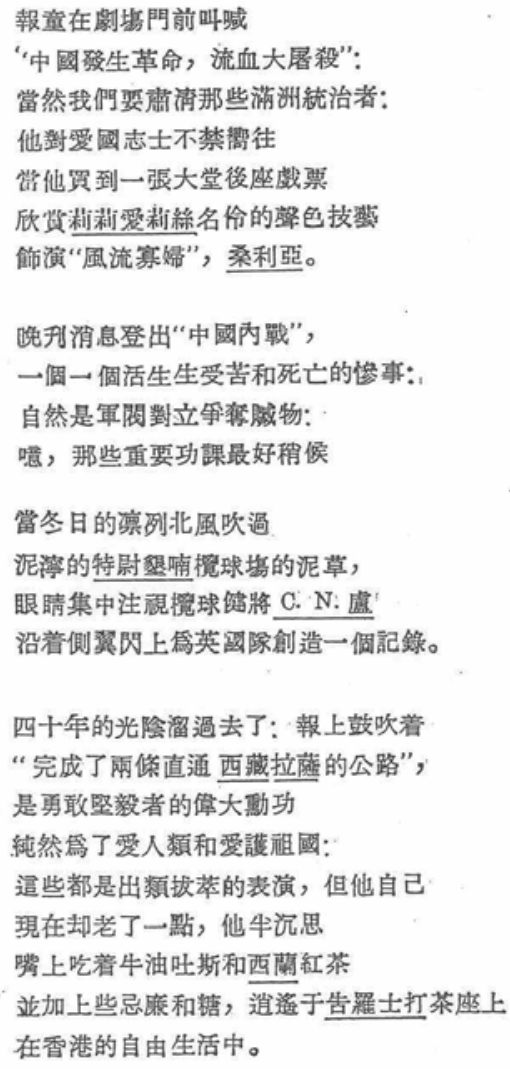

The first editions blazoned "Floods in China", Details of thousands starved and homeless: Result of callous government And corrupt officials of course: $O$ put off studies till another day While the summer sun gleamed warm On the green turf at London's Oval, Better that he watched Hobbs with leisured grace Scoring a century for Surrey county.

Down the theatre queue the newsboys yelled "Revolution in China, bloody slaughters": One must get rid of those Manchus of course: How he admired these patriots While he acquired a seat in the Pit To enjoy Lily Elsie act and sing In the role of Sonia, "The Merry Widow".

The evening news billed "Civil War in China", Lurid tales of suffering and dead: Rival warlords in quest of loot of course: O those important lessons better wait

While the wintry wind blew cold Across the grassy mud at Twickenham, As his eyes down the touch-line followed C.N. Lowe Streaking for a try for England on the Wing.

Forty years on: the papers trumpeted "Completion of two new roads to Lhasa", Gigantic deeds by brave and hardy men For love of human race and native land: Good show of course, but for himself, Much too old now for service, he half-mused Munching buttered toast and drinkiag Ceylon tea With cream and sugar, at The Gloucester Lounge in the freedom of Hong Kong.

\section{Figure 4.2}


In its content and thematics, "Indulgence" can be positioned in the genealogy of an anticolonial critique traceable in Leung Ping-kwan's poem and the 1997 discourse on hybrid English Chinese identity. The poem postulates two nations - England, China - in structural terms, and delineates their opposition. Each of the four stanzas places side by side momentous events in China and the recreational pursuits of bourgeois English life. The epic versus the pastoral, or the dynamic of national upheaval versus the rhythm of a nation at leisure - the persona stands poised between these two contrary conceptions of the "national", committed to neither. He is intelligent enough to perceive the historical irony this dual perspective generates — the two very different life-choices it proffers but as a spectator of both, he reduces them to the same level in his consciousness. Thus, reading about the floods in China is no different from watching cricket at the Oval; admiring the Chinese revolutionaries is as enjoyable as the performance of an Edwardian actress; the Chinese warlords are like rugby players; and finally, the satisfaction of hearing news of modern progress on the Mainland is like the satiety of tea in the comfort of a Hong Kong salon. Bourgeois English lifestyles flow into the anglicized rituals of colonial Hong Kong, in an imperialized habitus whose outlook on global historical and social transformation is as complacent as it is trivializing. The interiority of the colonial subject is laid bare in his self-justifications in each stanza, and at precisely the moment in-between the lines on China and England _ - "O put off studies till another day"; "One must get rid of those Manchus of course"; "O those important lessons better wait"; "Good show of course". The subject in his habitual procrastination takes shape as a symptomatic expression of colonial psychology as trivializing fugue. 
In 1956, anglophone and sinophone groups in Hong Kong were almost completely segregated, and biliteracy in literary writing the rarest phenomenon. ${ }^{13}$ Publishing in Chinese alongside English institutes a kind of parity between the two languages, and can be seen to foreground the claims of an ethnonational identity and affiliation depressed by colonialism. Also, the bilingual gesture enables the poem's anticolonial critique to be accessible to both minority anglophone and majority sinophone readers. ${ }^{14}$ But arguably, as biliterate modality, the poem in parallel texts is far more radical than its thematics and contemporary positioning would allow. The parallel texts deliver one poem in two languages but there are no dates in the collection that identify and differentiate the texts as source and target — as there are in Leung's collection. There is also no available biographical or textual information within the collection or elsewhere in the minimalist archival references to Wong Man that enables a dating of the two texts and institutes a source-target distinction. ${ }^{15}$ In other words, the parallel texts do not show that the English version is prior and the Chinese text secondary - which may be designed to increase its ethnic Chinese readership and mass appeal. Nor do they show the reverse - which may suggest an alternative move of taking a Chinese anti-colonial critique into the very system of English, a kind of "empire-writes-back" through translation move.

Wong Man's poem, registering multiple subject positions and temporalities, will always exist in two languages. The two texts cannot be situated in a unilinear movement from one semiotic system - either one - to the other but need be moving with each reading and rereading toward and apart from each other in simultaneity. Or enacting an 
immobility, an impasse. The identity of the poem as utterance in two languages is its sameness and difference, a sameness and difference that invite but also resist both hybridity and synthesis. From this perspective, its identity as biliterate performance cannot be conceptualized in terms of self-other, self-othering, othering self. Indeed, it is arguable whether the issue of identity emerging from a binary or hierarchical formulation - however constituted - of self and other, English and Chinese, can have any relevance at all.

In the absence of dates, a reading of the parallel texts must necessarily focus on their Chinese English simultaneity. To say this is not to deny that there are two language systems, each with its own formal logic and culturalized semiotics. What does not arise is a subjectivity constituted of an origin in a linguistic code and that is divided against itself in being subjected to an alien code. At the same time, there is no sign of a subject constituted by its appropriation of an alien code into indigenous compass. Seen from this perspective, the subject of the poem as utterance is not anglophilic-sinophobic or sinophilic-anglophobic but simultaneously Chinese English, English Chinese. It must be posited as necessarily in two languages — with no self-other, hierarchical, coreperipheral or primary-secondary discriminations.

In 1997, the government's decision to make Chinese the medium of instruction in the majority of Hong Kong schools was consistent with the nationalistic language policies that mark the inauguration of many postcolonial states. In an irredentist climate, English bore the stigma of colonialism, and yet also continued to be claimed as a Hong 
Kong language and the point of distinction between Hong Kong as "world city" and other indigenous-language urban zones on the Chinese mainland and elsewhere in the region. As this article is written, the government's recent "fine-tuning" policy on medium of instruction has clearly not been able to manage public discontent. ${ }^{16}$ Amid the ongoing contest between official directed and school- and parent-centred actions to shape language policies, a Chinese English or anglophone sinophone simultaneity posits a conceptual challenge to modal transformation, a challenge that situates the two languages in a space of parity and as systems of formal exchange that predicate Hong Kong subjectivity and identity.

\section{“Going to My Parents’ Place on a Crowded Bus” and 「我家」(“My Home")}

\section{Going to My Parents' Place on a Crowded Bus}

I'm sandwiched by two unattractive men on a Citybus to the land of Sky

and Water. An hour's crossroad journey from one home to another Outside: the metamorphosis of high-rise glass buildings to fragile trees. Inside: ten pairs of eyes staring at my breasts involuntarily pressed against the back of a seat.

My lungs absorb enough foul-smelling air recycled from people's breath to choke a fatal enemy. Dignity I sacrifice for several hours with my family.

(Ho, 2007)

\section{我家}

早上由天瑞往金鐘 再往薄扶林 


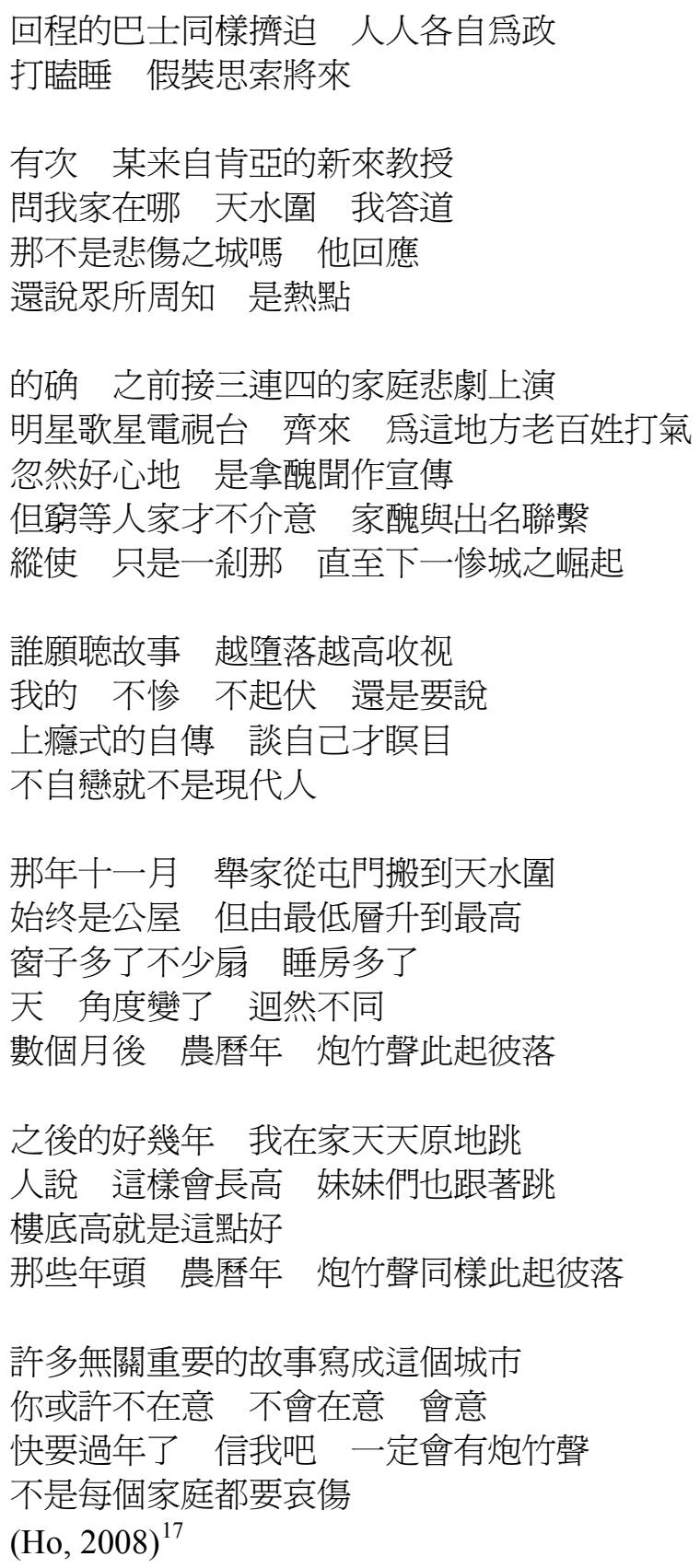

Tammy Ho Lai-ming's “My Parents’ Place” and 「我家」(“My Home”): the two titles set out the poems' cognate relations that their content and first person perspectives elaborate. The titles signify two temporalities that are continuous, contiguous but also 
discrete; between "my parents" home" and "my home" is the transition from childhood to adulthood. At the nexus of the poem's contemplation of transition is place: Tin Shui Wai (天水圍), apparent to the reader of the Chinese poem but veiled by the literal translation "the land of Sky / and Water" in the English poem. A new town in the northwest of the Hong Kong region, Tin Shui Wai is where the "I" grew up; it is where her parents live (in the English poem), and where she still does and calls "home" (in the Chinese poem). The Chinese poem invokes the memory of first arrival in the family's public housing flat, and childhood moments spent in the company of younger sisters. Place is also everyday: both poems begin with the familiar journey of an urban Hong Kong commuter and are crowded with vivid details so that the self, as it reflects on its own situation, is also unfolding in relation to its multiple familiar environments, past and present.

What is apparent and critiqued in the Chinese poem is the social stigma that has become attached to the name Tin Shui Wai in Hong Kong. It is the city of sadness ( $\ulcorner$ 悲 傷之城」), the tragic city ( $「$ 惨城」), populated by poor families ( $「$ 窮等人家」), where family tragedies one after another $(\ulcorner$ 接三連四的家庭悲劇 $\lrcorner)$ have been widely publicized by a media hungry for scandal ( $\ulcorner$ 醜聞 $\lrcorner) .{ }^{18}$ None of this is on view in the English poem, displaced by the lyrical "land of Sky / and Water" that transforms both family and place into pastoral idyll at the end of the first-person's commute, and makes the "sacrifice", that is, the acute indignities of the trip, bearable (Or is it the family who demands the "sacrifice"?). From their different narratorial vantages, both poems posit family as place and the family in place. The English poem underlines the emotional logic of "sacrifice" invoked against everyday depredations on the woman's self. In the Chinese 
poem, the negativity of this logic disappears as family and kinship enable a counternarrative of the self to the oppressive discourse of Tin Shui Wai's urban angst.

In narrating its relations with myriad Hong Kong others, the "I" as Hong Kong subject emerges, a hybridized construct of lived experience and linguistic artefact. The poems acknowledge this emergence, implicitly in the English version, and much more self-consciously in the Chinese:

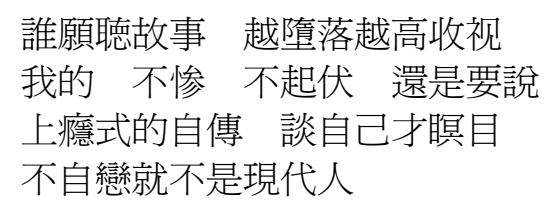

who wants to listen to stories the lower the fall the higher the tv ratings mine not tragic no rise and fall still has to be told (/ still has to tell) addictive autobiography (/autobiography as a kind of addiction) [we] talk about ourselves so [we] rest (/ die) content

[you're] not narcissistic (/ self-enamoured) [you're] not modern (/ a modern person)

(Translation mine) $^{19}$

Furthermore, the movements that identify and separate the two poems also suggest that the "I" may have different addressees in mind. This goes beyond the obvious point that readers who are monoliterate will get an impression of Tin Shui Wai and the first-person persona very different from those who can read both poems. In the English poem, the "I" becomes highly conscious of itself as a body sexualized by the others' gaze, and invaded by the others' breath. This is contrasted with the renaturalization produced by the subjective gaze as "high-rise/glass building" is metamorphosed "to fragile green trees". In this movement, the English poem has translated one woman's commute that begins please see my changes to note 19 to understand my changes to the punctuation of your translation. The usage of slashes for alternative meaning would be confusing, since slashes are conventional in poetry to denote a line break; but I understand your intention. Therefore I enclosed the alternative meaning within parentheses (what round brackets are called). For the pronouns implied in the Chinese, I used square brackets (which are just called brackets usually). I think square brackets would work very well since they often denote what is implied but not explicitly written, and helps comprehension. 
recognized by women urban commuters anywhere. In contrast, the Chinese poem is more "thickly" localized: it imbricates childhood and family with the adverse perceptions of Tin Shui Wai circulating within Hong Kong. To readers of the English poem, these perceptions do not pertain, not least because "the land of Sky / and Water" and the experiential and narrated "I" can be discerned without any knowledge of Tin Shui Wai as place. That the Chinese poem appears addressed to readers for whom Tin Shui Wai has specific historically situated meanings is reinforced by the ending:

快要過年了 信我吧 一定會有炮竹聲

不是每個家庭都要哀傷

the new year is coming trust (/ believe) me there will be firecrackers not every family has to be sad (/ wants sadness)

(Translation mine)

The implicit “you” addressed in $\ulcorner$ 信我吧」 (“trust/believe me") can include actual residents of Tin Shui Wai and/or an imagined community of Hong Kong Chinese readers for whom the new town has become synonymous with blighted families. The poem may circulate in the sinophone world outside Hong Kong but there, its effect as "local" will not deliver the same impact, and it will be more like the English poem. In other words, the poems generate different affective communities among whom the name "Tin Shui Wai"”comes replete with or depleted of local content.

In their different readerships, the two poems, as biliterate performances, are also diglossic; the Chinese English languages set up a traffic between biliteracy and diglossia. The poems map the two cultural geographies, external and internal, of Hong Kong writing but the relation between them is not a movement from local to global or vice 
versa, or local and global arranged in binary, hierarchical or equivalent order. Instead, the poems inscribe and transcribe the traffic between the two geographies as linguistic, or more precisely, as predicated on the strategic manipulations of biliteracy and diglossia. The "I" in both poems may begin from the same nexus of local origin: family, childhood, Tin Shui Wai, everyday. But the "I" that emerges from both poems has departed from these origins; through a biliterate diglossic practice which is both communicative and aesthetic artefact, it develops multiple resonances in different discursive encounters.

In positioning Tammy Ho's poems as the third in the three sets of texts, it is not my intention to give them any special privilege as contemporary though they may seem so because of their investment in a rhetoric of identity performance that has enjoyed recent currency. Each of the sets is modal but not singular; intermodality can be posited, to adapt Hayot et al., in terms of a "chiasmus, the old made present in the now, the now justified and given value by its structuring relation to [the] ... past" (ix). At this point, biliteracy exceeds reading and writing to affirm its end in poeisis and self-and worldmaking.

The discussion in this chapter focused on three actual sets of Chinese-English texts in Hong Kong and their different ramifications as biliterate language practice and performance. Taking its cue from translation studies, the discussion of these texts considers criteria of equivalence as well as their displacement. It explores proximity and distantiation between the two languages at a number of levels: from the practical level of language use and effects to metalinguistic critique of the discourses of origin and power 
as they operate in culture. As tropes of cultural identity, these biliterate language acts speak of encounters with forces that shape individuals and communities and connect them with others globally. The three acts co-exist in contemporary Hong Kong, and as modalities of biliteracy, they present tactical advantages that demand far greater attention than the controversy over medium of instruction can comprehend or allow.

\section{Notes}

* Part of the research for this chapter is supported by grant from the General Research Fund, University Grants Council, HKSAR. I would like to thank my colleagues, Janny Leung, Katherine Chen, and Chris Hutton for sharing with me their knowledge on bilingualism and the language situation in Hong Kong. 
1 The recent policy paper on "fine-tuning" the medium of instruction defines its objectives as follows: "Hong Kong needs to enhance its position as a modern international city and a global financial centre for sustained economic growth. Hong Kong also has a key role to play in contributing to the prosperity and development of our country. For these, we must equip our students with the requisite proficiency in both Chinese and English. Further, we are entering a new era as globalization has taken hold, and our younger generation will meet unprecedented challenges of the ever-changing environment. Our education system, including the curriculum and pedagogies, has to progress in tandem. The New Senior Secondary academic structure to be implemented this September will provide a wide and broad curriculum so as to enable our students to achieve all-round development and to lay the foundation for life-long learning. To learn how to learn, our students must master the skills to collate information, identify and analyze the issues involved, and articulate their opinions. All these require a good command of both Chinese and English." From discussion paper of the Legislative Council Panel on Education: Fine-tuning the Medium of Instruction for Secondary Schools, 15 Jan 2009, http://www.legco.gov.hk/yr11-12/english/panels/ed/papers (accessed June 1, 2009).

${ }^{2}$ For a summary account of biliteracy and trilingualism and the medium of instruction, see Adamson.

${ }^{3}$ See Bhatia and Ritchie for the areas of interest in bilingualism, and within this framework, a discussion of the Hong Kong situation by Li and Lee.

${ }^{4}$ These earlier studies need to be supplemented by the work of Katherine Chen on code mixing and code switching differentiations between Hong Kong Cantonese speakers and returnees who have studied or lived in anglophone countries for an extended period of time. Chen's study takes into account the changing demographics of the local population where older triangulations between mainland China, Hong Kong, Britain/United States, are complicated by mobile and diasporic ethnic Chinese subjects from different global locations. Some studies of code switching, however, disagree about whether the practice is sociolinguistically motivated. See the literature cited in $\mathrm{Li}$ and $\mathrm{Lee}_{2}$ 28.3.1.

${ }^{5}$ For a systematic discussion of literary translation and postcolonial writing as analogues of "intercultural writing", see Tymoczko, 1999a.

${ }^{6}$ For insightful discussions of Leung's work situated vis-à-vis 1997, see Chow, 1998 and 2002. Martha's Cheung's introduction offers an excellent overview of Leung's work (Leung, 2002, pp.19-35).

7 The exterior of the Main Building, most frequently identified with the university in the public recognition, is one of 84 "Declared Monuments" in Hong Kong. Any alteration or renovation is subject to official approval.

${ }^{8}$ See Ngũgĩ wa Thiong'o, “The Language of African Literature” (1985), rpt., and other essays in Ngũgĩ, 1986. For one of the best-informed and insightful studies of Ngũgĩ and his work, see Gikandi, 2002.

9 In one conception of "world literature" by David Damrosch, it is a "mode of circulation and of reading" (5) in which literary works move beyond their "culture of origin, either in translation or in their original language" (4). This conception is not directed towards canon formation though the actual choice of texts in Damrosch's study can be seen to posit the criteria of selecting works that enter into global circulation.

${ }^{10}$ Franco Moretti's conception of "world literature" is much more systemically oriented than Damrosch's. It presupposes quasi-organic links between national literatures as resources from which texts for collections and anthologies of "world literature" can be derived. In its actual institutional organization, "world literature" appears to reinvent a hierarchy between national literature specialists as peripheral and theorists of "world literature" at the centre. In Moretti's schema, Leung's poem would be positioned as "national" literature, and Leung himself as Chinese literature specialist - with all the irony they imply.

${ }^{11}$ I am adapting the well-known use of cultural "worlding" by Gayatri Spivak (Spivak, 1985, p. 262) as the incorporation of a "native" project into imperial cultural governance.

${ }^{12}$ Wong Man was from a rich comprador family in Hong Kong. After qualifying as a medical doctor in England, he practised in a London public hospital before returning to Hong Kong. In the 1930s, he went on to Shanghai to look after Chinese soldiers injured in the war against Japan. There, he befriended leftist intellectuals and public figures including Soong Qingling (Madame Sun Yat-sen). From Shanghai, he travelled to Guangzhou (Canton) where he helped set up the Chinese branch of the International Red Cross. After 1949, he returned to Hong Kong where he continued to practise as a doctor, and also translated and wrote poems. As a writer and historical figure, Wong Man has long been consigned to collective oblivion. His name, as far as I know, is not mentioned in any of the anthologies or narratives of Hong Kong literature. 
I have written elsewhere of what little is known of Wong, his significance, and that of his writing in poetic and other genres in the cultural-historical contexts of 1950s Hong Kong and the Cold War (Ho, 2009b).

13 Eileen Chang Ailing was possibly the only other and more famous writer who wrote and published in both languages.

14 This issue is discussed in another essay (Ho, 2009b), but situated in Hong Kong literary culture during the Cold War and Wong Man's other writing and cultural activities.

15 There are two main sources of biographical information on Wong: his series of essays, "Bygone Travel Notes" about his early childhood, in the English-language magazine, Eastern Horizon, II (1962-3), published in Hong Kong, and the obituary, "In Memory of Dr Wong Man," by J. M. and Rose W. Y. Tan, Eastern Horizon, III:1 (January 1964), 62-63. A copy of Between Two Worlds signed by Wong himself and dedicated to Chan Kwan-Po, former librarian of the Fung Ping-shan Chinese library, is in the Hong Kong Collection, University of Hong Kong Library.

${ }^{16}$ At a meeting of education groups, the chairman of the Association of Heads of Secondary Schools is reported to have said: "The changes [in the 'fine-tuning' policy] are obviously in response to some complaints about students' poor English under mother-tongue education. We are not saying students need not brush up on their English, but the new policy cannot serve the purpose. It will worsen the labelling effect on students who remain in Chinese classes" $(\mathrm{Ng}, 2009)$. In their response to the government's discussion paper on fine-tuning, the Association of English Medium Secondary Schools writes: "We agree that mixed-code teaching, e.g. the use of English textbooks with classroom instruction in Chinese, should not be allowed, as this will seriously compromise the students' ability to speak and write well in English. While some Chinese terms may be used in an initial bridging programme in Secondary I, this should not last for more than three months" (http://www.legco.gov.hk/yr11-12/english/panels/ed/papers/ed_m1.htm, accessed June 7, 2009). Here, the example of "mixed-code teaching" is another of the variants on what mixed-code in the classroom can entail. It implicitly maintains the separation between Chinese speech and English writing even as it posits the co-presence of the two in the classroom as "mixed-code". The responses of the two groups suggest they perceive the "fine-tuning" policy and its aims quite differently.

17 According to Tammy Ho, "The poem was written in 2008, shortly before Lunar New Year. I was struck by how much media attention Tin Shui Wai (where my parents and sisters live) received then and wondered how much of that excessive attention was genuine. I disliked the label that the town had 'earned': Town of Sadness 悲傷之城. It's not only an untrue description of the place, it's also an unfair comment affecting all the citizens living in Tin Shui Wai. At the end of the day, I thought there are many humble and decent families leading a normal life, and it is their stories that build the town, and Hong Kong as a whole" (Ho, 2008).

${ }^{18}$ For an article, "Tin Shui Wai : City of Sadness", written in December 2007 at around the same time as Tammy Ho's two poems, see

http://www.asiasentinel.com/index.php?Itemid=149\&id=934\&option=com_content\&task=view. See also the Hong Kong filmmaker, Ann Hui On-wah's diptych on Tin Shui Wai, The Way We Are (2008) and Night and Fog (2009). The Chinese language website, http://www.tinshuiwai.com.hk/, posts community information and activities.

${ }^{19}$ For the purpose of this chapter, my translations are literal, which means including the alternative meanings of the Chinese characters within parentheses and after a slash. The pronouns in brackets are not in the Chinese original but are implied in the grammar.

\section{References}


Adamson, Bob (forthcoming). Language Policy and the Medium of Instruction, in P. Morris and B. Adamson (eds), Curriculum and Schooling in Hong Kong (Hong Kong: Hong Kong University Press).

Arac, Jonathan (2002). Anglo-Globalism? New Left Review 16, pp. 35-45.

Basnett, Susan and André Lefevere (eds)(1990). Translation, History and Culture (London: Pinter).

Basnett, Susan and Harish Trivedi (eds)(1999). Post-colonial Translation: Theory and Practice (London and New York: Routledge).

Benjamin, Walter (1992). The Task of the Translator. Illuminations, trans. H. Zohn (London: Fontana), pp. 70-82.

Bermann, Sandra and Michael Wood (eds)(2005). Nation, Language and the Ethics of Translation (Princeton: Princeton University Press).

Chan Hok-shing, Brian (1998). "How does Cantonese-English code-mixing work?" in Martha C. Pennington (ed.), pp. 191-216.

Chan, Stephen C. K. (ed.)(1997). Cultural Imaginary and Ideology (《文化想像與意識 形態》)(Hong Kong: Oxford University Press)(in Chinese). 
Cheyfitz, Eric (1997). The Poetics of Imperialism: Translation and Colonization from The Tempest to Tarzan (Philadelphia: University of Pennsylvania Press).

Chow, Rey (1998). Things, Common/Places, Passages of the Port City: On Hong Kong and Hong Kong Author Leung Ping-kwan, in Ethics After Idealism, pp. 168-87 (Bloomington, Indiana: Indiana University Press).

Cronin, Michael (2000a). History, Translation, Postcolonialism, in Sherry Simon and Paul St-Pierre (eds), Changing the Terms: Translating in the Postcolonial Era (Ottawa: University of Ottawa Press), pp. 33-52.

(2000b). Across the Lines: Travel, Language, Translation (Cork: Cork University Press).

(2006). Translation and Identity (London: Routledge).

Damrosch, David (2003). What Is World Literature? (Princeton: Princeton University Press). 
De Certeau, Michel (1988). The Writing of History, trans. Tom Conley (New York: Columbia University Press).

Duarte, João Ferreira, Alexander Assis Rosa and Teresa Seruya (eds)(2006). Translation Studies at the Interface of Disciplines (Amsterdam: John Benjamins).

Gentzler, Edwin and Maria Tymoczko (eds)(2002). Translation and Power (Amherst, MA: University of Massachusetts Press).

Gikandi, Simon (2002). Ngugi wa Thiong’o (Cambridge: Cambridge University Press).

Hayot Eric, Haun Saussy, Steven G. Yao (2008). Sinographies: Writing China (Minneapolis: University of Minnesota Press).

Ho, Elaine Yee Lin (2009a). ‘Imagination’s Commonwealth': Edmund Blunden’s Hong Kong Dialogue, PMLA 124:1, pp. 76-91.

Ho, Elaine Yee Lin (2009b). Nationalism, Internationalism, the Cold War: Crossing Literary-Cultural Boundaries in 1950s Hong Kong, in Elaine Y. L. Ho and Julia Kuehn (eds), China Abroad: Travels, Subjects, Spaces (Hong Kong: Hong Kong Univerity Press), pp. 85-103. 
Ho, Tammy Lai Ming (2007). Going to My Parents' Place on a Crowded Bus, in Spokenwar, rpt. Concelebratory Shoehorn Review (2008),

http://concelebratory.blogspot.com/2008/07/tammy-ho-going-to-my-parents-houseon.html (accessed June 2, 2009).

Ho, Tammy Lai Ming (2008). My Home, in Poetry Sky Quarterly : Chinese Journal, rpt. http://www.poetrysky.com/chinese/2/heliming.html (accessed June 2, 2009).

Huyssen, Andreas (2003). Present Pasts: Urban Palimpsests and the Politics of Memory (Palo Alto, CA: Stanford University Press).

Leung, Matthew Wing-kwong (2006). The Ideological Turn in Translation Studies, in João Ferreira Duarte, Alexandra Assis Rosa and Teresa Seruya (eds), Translation Studies at the Interface of Disciplines (Amsterdam: John Benjamins), pp. 129-44.

Leung Ping-kwan (2002). Travelling with a Bitter Melon: Selected Poems (1973-1998) (《帶一枚苦瓜旅行》), ed. Martha P. Y. Cheung (Hong Kong: Asia 2000 Ltd.)(in English and Chinese).

Li, David C. S. (1996). Issues in Bilingualism and Biculturalism: A Hong Kong Case Study. Berkeley Insights in Linguistics and Semiotics, Vol. 21 (New York: Peter Lang). 
Li, D. C. S. and Sherman Lee (2005). Bilingualism in East Asia, in Tej K. Bhatia and William C. Ritchie (eds), The Handbook of Bilingualism, Chapter 28 (Oxford: Blackwell).

Moretti, Franco (2000). Conjectures on World Literature. New Left Review 1, pp. 54-68.

— (2003). More Conjectures. New Left Review 20, pp. 73-81.

Ng Kang-chung (2009). Language policy Under More Fire, in South China Morning Post, June 1 (Hong Kong).

Ngũgĩ wa Thiong'o (1986). Decolonizing the Mind: the Politics of Language in African Literature (London: James Currey).

Niranjana, Tejaswini (1992). Siting Translation: History, Post-structuralism, and the Colonial Context (Berkeley, CA: University of California Press).

Niranjana, Tejaswini (2002). Post-colonial Representation: Translation as Disruption, in Translation, Text and Theory: The Paradigm of India, ed. Rukmini Bhaya Nair (New Delhi and London: Sage), pp. 55-76.

Pennington, Martha C. ed. (1998). Language in Hong Kong at Century's End (Hong Kong: Hong Kong University Press). 
Robinson, Douglas (1997). Translation and Empire (Manchester: St Jerome).

Saussy, Haun (2008). Media Creoles and the Invention of Delüfeng. Conference presentation, Cambridge University.

Sherry, Simon and Paul St-Pierre (eds)(2000). Changing the Terms: Translating in the Postcolonial Era (Ottawa: University of Ottawa Press).

Spivak, Gayatari Chakravorty (1985). Three Women's Texts and a Critique of Imperialism, rpt. in Henry Louis Gates, Jr. (ed.)(1986), “Race,” Writing, and Difference (Chicago: Chicago University Press), pp. 262-80.

Tej K. Bhatia and William C. Ritchie (eds)(2005). The Handbook of Bilingualism (Oxford: Blackwell).

Tymoczko, Maria (1999a). Post-colonial Writing and Literary Translation, in Susan Basnett and Harish Trivedi (eds), Post-colonial Translation: Theory and Practice (London and New York: Routledge), pp. 19-40.

(1999b).Translation in a Postcolonial Context: Early Irish Literature in English Translation (Manchester: St Jerome). 
(2000). Translations of Themselves: the Contours of Postcolonial Fiction, in

Sherry Simon and Paul St-Pierre (eds), Changing the Terms: Translating in the Postcolonial Era (Ottawa: University of Ottawa Press), pp. 147-63.

Venuti, Lawrence (ed.) (1992). Rethinking Translation: Discourse, Subjectivity, Ideology (London: Routledge).

Wong, Man (1956). Between Two Worlds (Hong Kong: The Student Bookstore).

Wong Wang-chi (2000). The Burden of History: A Hong Kong Perspective of the Mainland Discourse of Hong Kong History (Hong Kong: Oxford University Press)(in Chinese). 王宏志, 《歷史的沉重: 從香港首中國大陸的香港史論述》〈香港: 牛津 出版社〉。

— (2007). Local Hong Kong (Hong Kong: Cosmosbooks)(in Chinese). 《本土香 港》〈香港: 天地圖書有限公司〉。

Wong Wang-chi, Li Siu-leung and Chan Ching-kiu Stephen (1997). Hong Kong Unimagined: History, Culture and the Future, ed. David D. W. Wang (Taipei: Maitian)(in Chinese). 王宏志、李小良、陳清僑, 《否想香港: 歷史、文化、未來》, 王德威 主編〈臺北: 麥田出版有限公司〉。 